\title{
Benefits of Nanomedicine for Therapeutic Intervention in Malignant Diseases
}

\author{
Ani-Simona Sevastre ${ }^{1,+} \mathbb{D}$, Cristina Horescu ${ }^{2,+}$, Stefania Carina Baloi ${ }^{2}$, Catalina Elena Cioc $^{2}$, \\ Bogdan Ionel Vatu ${ }^{2}$, Cristian Tuta ${ }^{2}$, Stefan Alexandru Artene ${ }^{2}$, Maria Mihaela Danciulescu ${ }^{2}$, \\ Stefania Tudorache ${ }^{2, *}$ and Anica Dricu ${ }^{2, *}$ \\ 1 Faculty of Pharmacy, University of Medicine and Pharmacy of Craiova, Str. Petru Rares nr. 2-4, \\ Craiova 710204, Romania; anifetea_umf@yahoo.com \\ 2 Faculty of Medicine, University of Medicine and Pharmacy of Craiova, Str. Petru Rares nr. 2-4, \\ Craiova 710204, Romania; crsu100@gmail.com (C.H.); carina_baloi@yahoo.com (S.C.B.); \\ catalinaelena266@yahoo.ro (C.E.C.); bogdan_vatu@yahoo.com (B.I.V.); tutacristi@yahoo.com (C.T.); \\ stefan.artene@yahoo.com (S.A.A.); danciulescum@yahoo.com (M.M.D.) \\ * Correspondence: stefania.tudorache@gmail.com (S.T.); anica.dricu@live.co.uk (A.D.); \\ Tel.: +40-0351-443-500 (A.D.) \\ + These authors contributed equally to this study.
}

Received: 29 August 2019; Accepted: 26 September 2019; Published: 29 September 2019

\begin{abstract}
Cancer remains one of the most difficult to manage healthcare problems. The last two decades have been considered the golden age of cancer research, with major breakthroughs being announced on a regular basis. However, the major problem regarding cancer treatment is the incapability to selectively target cancer cells, with certain populations of tumors still remaining alive after treatment. The main focus of researchers is to develop treatments that are both effective and selective in targeting malignant cells. In this regard, bioavailability can be increased by overcoming the biological barriers encountered in the active agent's pathway, creating carrier vehicles that have the ability to target malignant cells and effectively release the active agent. Since its appearance, nanomedicine has provided many answers to these challenges, but still, some expectations were not satisfied. In this review, we focused on the most recent developments in targeted drug delivery. Furthermore, a summary of different types of nanoparticles used to deliver active therapeutic agents in oncology is presented, along with details on the nanodrugs that were clinically approved by the Food and Drug Administration (FDA), until April 2019.
\end{abstract}

Keywords: cancer therapy; nanoparticles; targeted delivery

\section{Introduction}

Worldwide, cancer represents a global health crisis. Around 1,762,450 new cancer cases and about 606,880 cancer deaths are expected this year in the USA alone [1].

In recent years, new medications and treatment technologies were fueled by the development of the innovative research. The therapeutic options have steadily evolved from the classic options such as chemotherapy, surgery, and radiotherapy, which received constant updates, to newer, more refined options such as targeted therapy, stem cell transplant, and immunotherapy [2-6].

Despite this, each treatment option has its flaws and shortcomings, and more advanced approaches are required in order to overcome the mechanisms behind tumor treatment resistance.

Nanomedicine is an emerging field that started to offer some answers to those problems.

Nanocarriers have the ability to encapsulate drugs with low solubility, preventing a fast clearance and improving the bioavailability. The properties of nanotransporters allow them to target the tumor 
tissue and to release active ingredients in a stable and controlled manner [7]. The enhanced permeability and retention effect (EPR effect) of blood vessels allows nanoparticles (NPs) to accumulate inside the tumor, if they are not metabolized by the liver or spleen, nor excreted through the renal system [8].

Currently, a wide variety of organic and inorganic, viral and drug conjugated nanoparticles (NPs) are being investigated.

In this review, we will summarize the benefits and shortcomings of different types of nanoparticles used to deliver active therapeutic agents in oncology, along with details on the clinically approved nanodrugs.

\section{Nanotechnology in Cancer Therapy}

Generally, NPs are materials shaped in sizes ranging from 1 to $1000 \mathrm{~nm}$. They can be classified according to several criteria. Based on the type of material, they can be divided into four categories: carbon-based nanomaterials (fullerenes, carbon nanotubes, carbon nanofibers, carbon black, graphene, and carbon onions), inorganic-based nanomaterials ( $\mathrm{Au}, \mathrm{Ag}, \mathrm{TiO}_{2}, \mathrm{ZnO}$, silicon or ceramics NPs), organic-based nanomaterials (liposomes, dendrimers, micelles and polymeric NPs), and composite-based nanomaterials [9-12]. Based on electron movement, NPs can be classified in OD clusters and particles, 1D nanotubes and nanowires, or 2D nanoplates and layers [13]. Based on their origin, NPs can be natural, synthetic or engineered [14]. Depending on the type and structure of the nanomaterial, several models of nanoparticles can be obtained (Figure 1).

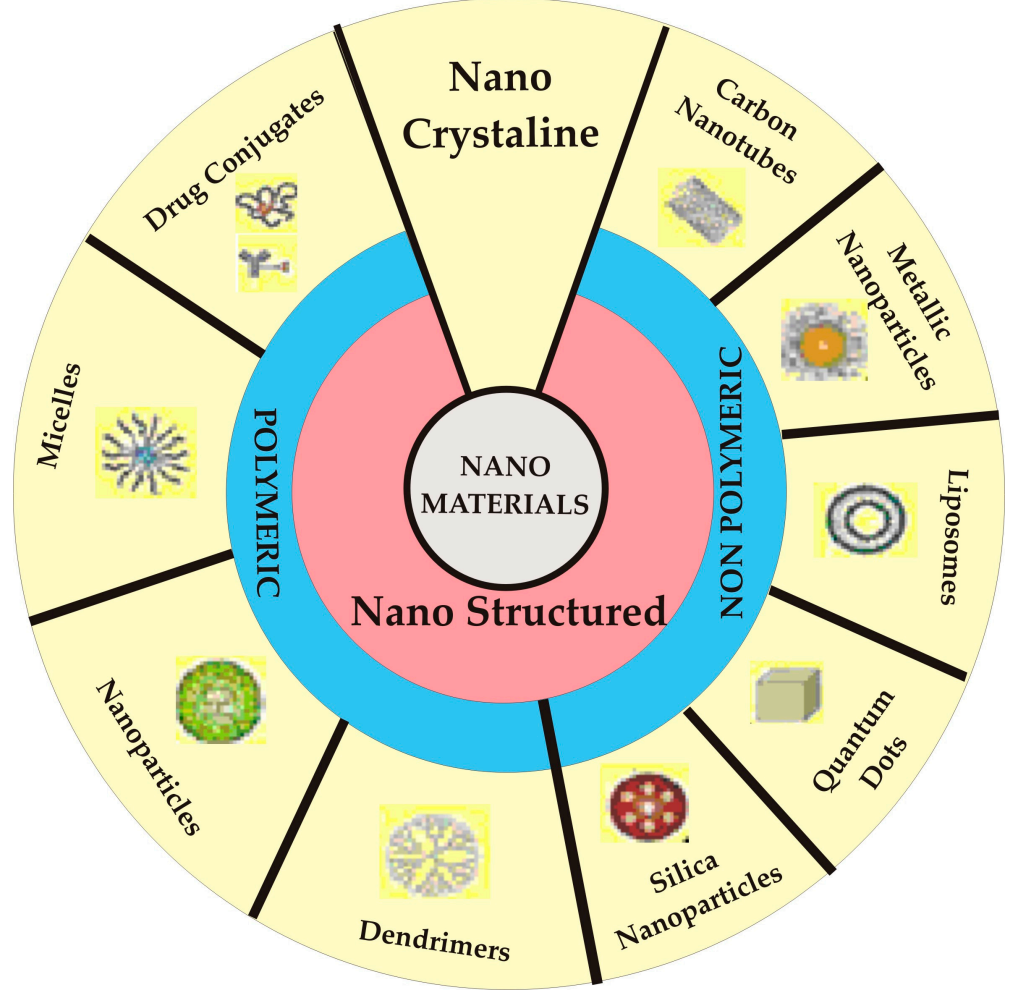

Figure 1. Illustrative representation of the different types of nanopharmaceuticals.

The most used NPs in oncology field are protein-drug conjugated, liposomal, polymeric and dendrimeric nanoparticles, hydrogels, carbon nanotubes, and gold and silver nanoparticles. In the last 30 years, extensive studies have focused on developing cancer nanosized pharmaceutical forms that are capable of overcoming the biological barriers and that can effectively transport the active principles to the targeted sites, with minimal harmful effects in healthy tissues [15]. Over time, several types of nanotransporters have been created, as it can be observed in the Figure 2. 


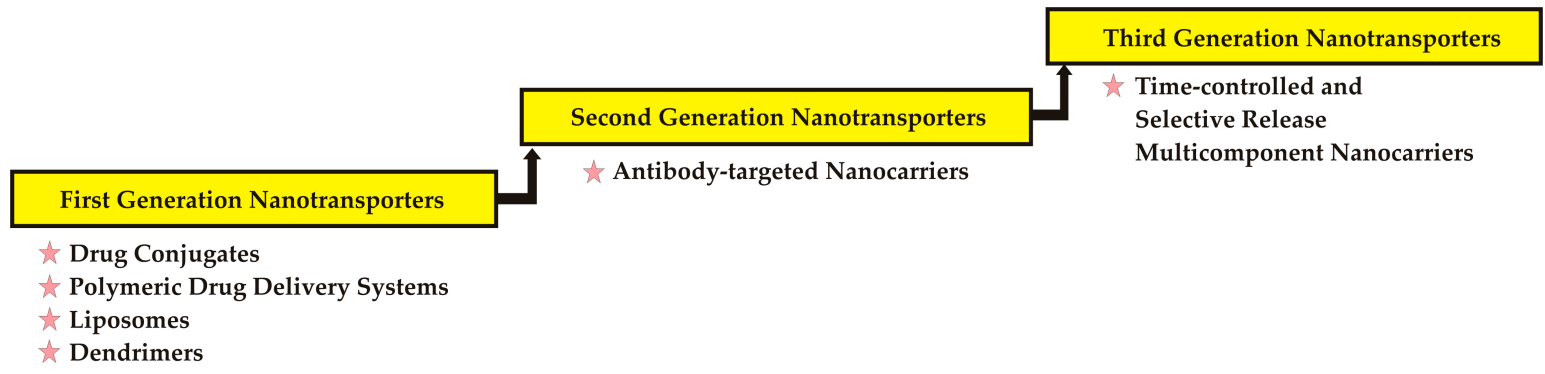

Figure 2. Evolution of nanocarriers.

\section{Modeling Bioavailability-A Real Challenge in Oncology Research}

A large number of studies have shown the capacity of nanoparticles to detect and kill cancer cells both in vitro (cell cultures) and in vivo (mouse models). Despite all that, the clinical use of nanoparticles is still limited because of the physical and biological barriers that they have to face after administration [16]. For example, the bioavailability of systemically administrated NPs is highly influenced by diffusion, aggregation, protein adsorption, flow and shear forces, renal clearance, and phagocytic sequestration [17-19].

Many factors can influence nanoparticle's drug delivery, such as sizes, shape, surface chemistry, reactivity, encapsulation capacity, transport mechanisms, ability to escape the clearance systems [20]. They are outlined in the Figure 3.

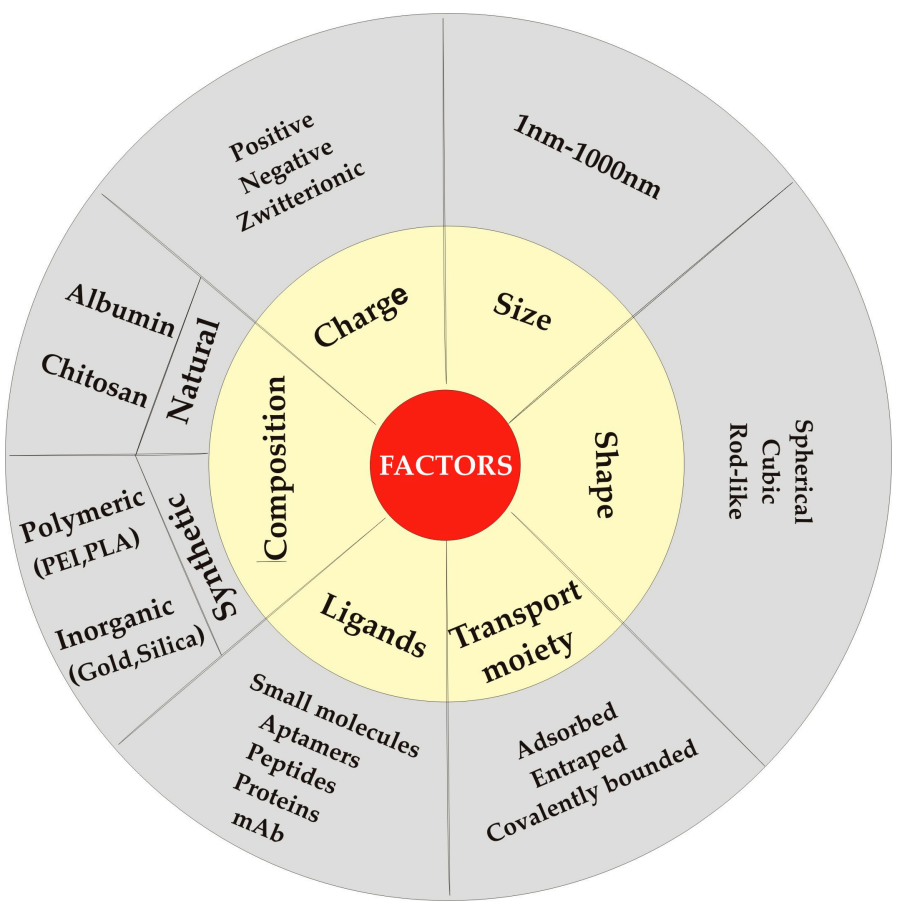

Figure 3. Factors influencing drug delivery from nanoparticles.

Broadly, the size of nanoparticles ranges from 1 up to $1000 \mathrm{~nm}$ and it is a critical factor that influences blood circulation, which in turn is related to drug release and tumor accumulation and retention. The type of material is also important in establishing the delivery efficiency. For example, inorganic nanoparticles tend to provide a higher delivery efficiency than those made from organic materials ( $0.8 \%$ compared to $0.6 \%$ of the injected dose (ID) in mouse models) [21].

Along with the type of material used, the shape of the nanocarriers is a crucial factor in determining the pharmacokinetic behavior in vivo in terms of time of residence in the gastrointestinal tract and ability to overcome rapid clearance. For example, mesoporous silica rod nanoparticles orally administered in 
mice had a longer residence time in the gastrointestinal tract compared with the spherical nanoparticles and exhibited longer blood circulation than the spherical nanoparticles, which were cleared faster by the renal system [22].

The stability and distribution of nanocarriers in the blood are also affected by their charge. Tumor vessels are more effectively targeted by positive charged nanoparticles. After extravasation from tumor vessels, a better diffusion is achieved by using neutral charged nanocarriers, compared with the positive or negative ones [23]. Also, endocytosis and cellular uptake in tumor tissue can be improved by modeling the nanocarrier's surface [24]. Neutral zeta potential-nanoparticles tend to have higher delivery efficiency than negative or positive zeta potentials-NPs $(0.7 \%, 0.6 \%$ and $0.5 \%$ ID) [21].

The nanoparticles have the special ability to encapsulate different active drugs, improving several characteristics such as solubility, degradation rate, clearance, and targeting properties. Hydrophilic nanoparticles are used to encapsulate poor solubility drugs. Also, the nanoparticles characteristics can be upgraded with various modifications: coating, surface charge, functional groups or targeting moieties attachment. By coating them with polyethylene glycol (PEG), the stability and solubility of the nanoparticles-and therefore the bioavailability of the drug - is increased. In order to make them target specific, the surface may also be bound with different ligands (specific molecules for the over expressed cancer ligands such as glycans) [25].

NPs have different abilities to cross the barriers. By using different routes of administration, many types of molecule, and even particles, can be delivered across natural body barriers.

In the active agent's route to the target site, it may encounter several biological barriers that can significantly influence the therapeutic effect, such as the reticuloendothelial system (RES), renal system and, for central nervous system (CNS) drugs, the blood-brain barrier (BBB) [26], but other challenges specific to each pathology are to be overcome. The extracellular and intracellular barriers are mentioned in the Figure 4.

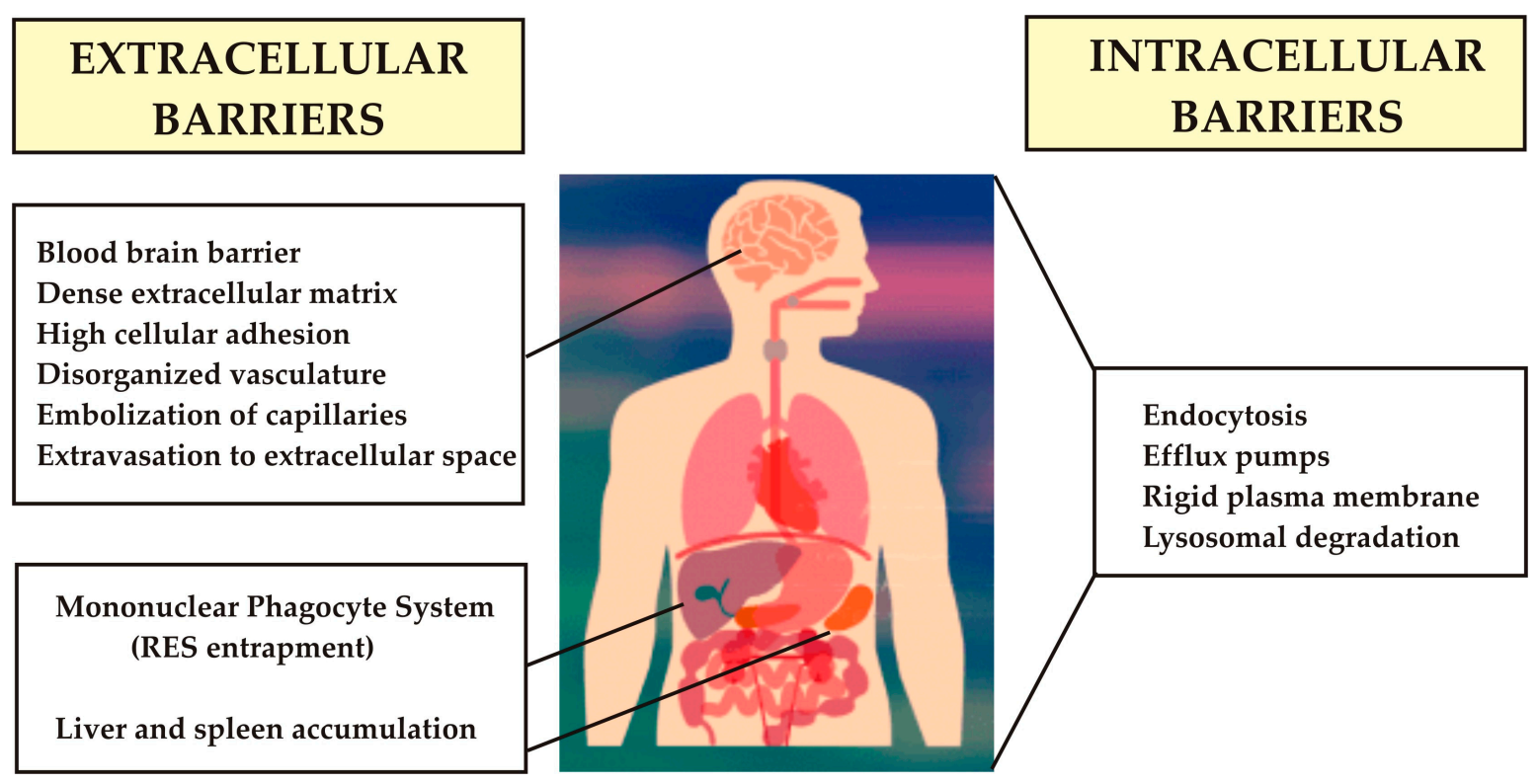

Figure 4. Biological barriers.

Part of the immune system, the RES consists in phagocytic cells like monocytes and macrophages. By binding to nanoparticles, phagocytic cells trigger cytokine release, resulting in the faster removal of nanoparticles from systemic circulation. The nanoparticles clearance may also be increased by binding different types of macromolecules to their surface [27-29].

A solution to these problems would be to modify the surface of nanoparticles by the following methods: attaching zwitterionic ligands (cysteine, glutathione) or polyethylene glycol 
(PEG-ylation) [30], coating the surface with biocomponents derived from blood cells like erythrocytes and leukocytes [31] or providing spherical shapes that prevent interactions with endothelial cells [32].

In addition to particle recognition by the host immune system, the renal system is also important in nanoparticles (NPs) bioavailability. Besides shape, both the dimensions and the positive or negative charge of nanoparticles may influence the process of renal filtration. It has been demonstrated that the positive spherical nanoparticles, with a 6-8-nm diameter have a good renal clearance when inoculated in mice [22,33]. Even if they have a relatively large molecular mass, the nanotubes of $L=100-500 \mathrm{~nm}$, $\varnothing=0.8-1.2 \mathrm{~nm}$ can easily pass through the fenestrated capillary endothelium [34]. In the case of kidney disease, the necessary dimensions may fluctuate.

The BBB is the main cause why treatments generally fail when directed at the brain. This barrier is constituted of endothelial cells joined by junctions and enclosed by basal lamina, astrocytic cells, pericytes, and microglia. The large-molecule neurotherapeutics cannot cross the BBB and only approximately $2 \%$ of small-molecule drugs can traverse it [35]. Therefore, treating neurological, infectious, and neurodegenerative diseases with systemic drugs is a daunting challenge due to the specific protective barriers found in the CNS.

Increasing penetration through the BBB is one of the most challenging problems. By direct introduction of the drug (intraventricular or intracerebral injection, infusion, and implantation), the toxicity risks may increase, and the drug is non-uniformly dispersed [29]. Other more convenient methods to treat brain diseases are emerging.

The nanoparticles can pass through the BBB by receptor-mediated endocytosis [36,37]. In this regard, surfactants like Tween 80 or Poloxamer 188 were used to coat nanoparticles to increase adsorption of serum proteins [38]. Human serum albumin-coated nanoparticles may be covalently attached to apolipoproteins to improve their absorption [39]. For the same purpose, lactoferrin, transferrin, and low-density lipoprotein (LDL) receptors were used as targeting ligands for the endothelial cells receptors in mice models [40-42]. Size and charge are important aspects for passing through the BBB, with nanoparticles with a size of $50 \mathrm{~nm}$ being preferential for transport in vitro using bEnd.3 model [43]. Also, the anionic and neutral nanoparticles were proven to be less neurotoxic than the cationic ones in an experiment involving murine models [44].

The mechanisms of distribution and the targeted delivery are two crucial aspects involved in optimizing NPs bioavailability. The transcellular extravasation is thought to be involved in NPs pathway. The vesiculo-vacuolar organelles (VVOs) contained in the normal venule and capillary endothelial cells are thought to offer a pathway for the extravasation of plasma components during induced acute vascular hyperpermeability [45]. Cancer tissues are characterized by leaky vasculature with many fenestrations and with low pericyte coverage. Because of the intercellular extravasation, nanoparticles may be passively accumulated in the tumor. This is due to the pressure generated by poor lymphatic drainage, also known as enhanced permeability and retention (EPR) effect. Because of this, fenestrated blood vessels tissues (liver, spleen) have high chances to accumulate NPs via passive targeting [46]. These features have been used to formulate high bioavailability pharmaceutical forms administered in different types of cancer [47]. The mechanisms of active and passive targeting are illustrated in the Figure 5.

Passive targeting is a size-dependent process, resulting from poor lymphatic drainage and of leaky vasculature. The enhanced permeation and retention (EPR) effect is the extravasation of particles in the tumor tissue, followed by their retention. Being foreign bodies, they are susceptible to be recognized by the mononuclear phagocyte system (MPS). However, by coating the nanoparticles with various materials such as PEG, the particles can escape the MPS capture. These drug delivery systems are referred to as stealth systems. Also, block copolymers can be used for surface modification of nanocarriers. One example is a product approved in 2007 in Korea and marketed in Europe, named Genexol-PM, a PEG-based block copolymer micellar formulation [48]. 

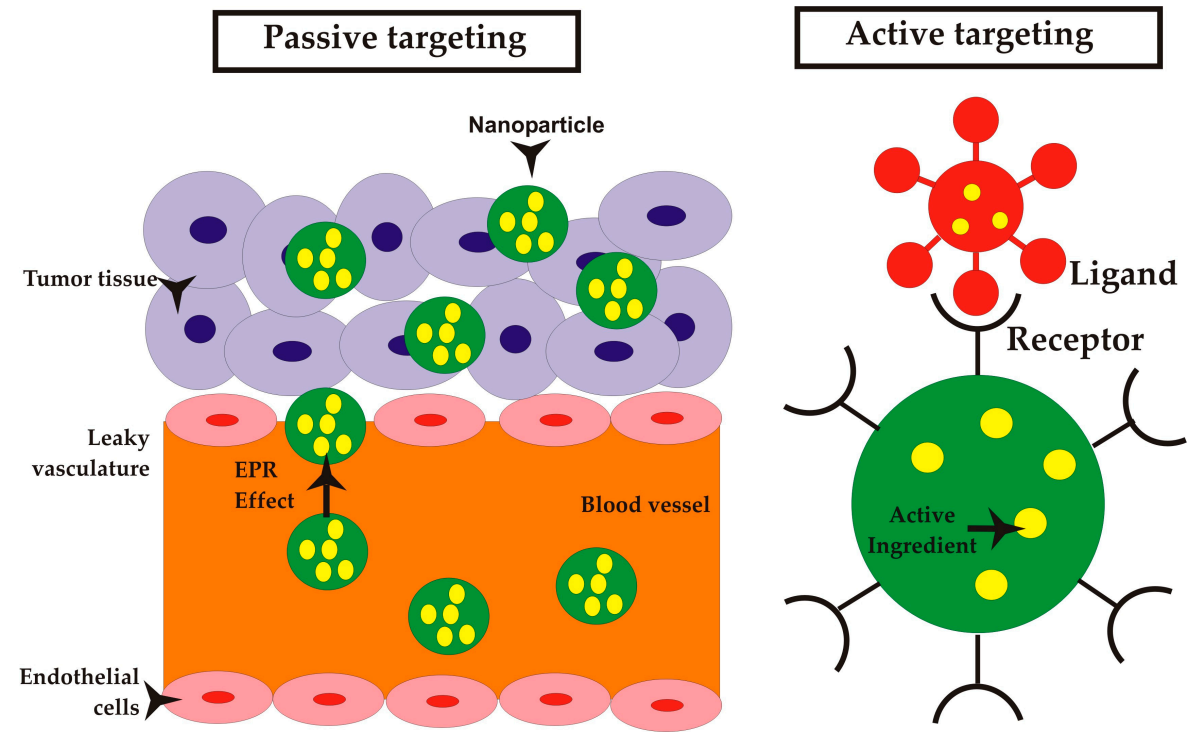

Figure 5. Mechanisms in drug delivery.

Active drug targeting approaches are much more complex than passive strategies. This type of targeting is based on the tumor cell membrane over-expressed receptors like transferrin and folic acid receptors, the tumor specific biomarkers like CA-125 for ovarian cancer, the phagocytosis/endocytosis mechanisms, and the specific processes like neoangiogenesis [49].

The nanoparticles have proven to be successful for controlled and targeted drug delivery. To overcome the aforementioned issues in brain cancer therapy, various nanotechnologies were employed. To increase the specificity for cancer targets, ligands attached to the surface of the nanocarriers were used for active targeting [50]. Such ligands are transferrin, antibodies, folic acid, enzymes, and macromolecules like proteins or carbohydrates [51-55]. In order to specifically target cancer cells, the nanoparticles surface may be optimized using different approaches, as it can be observed in the Figure 6.

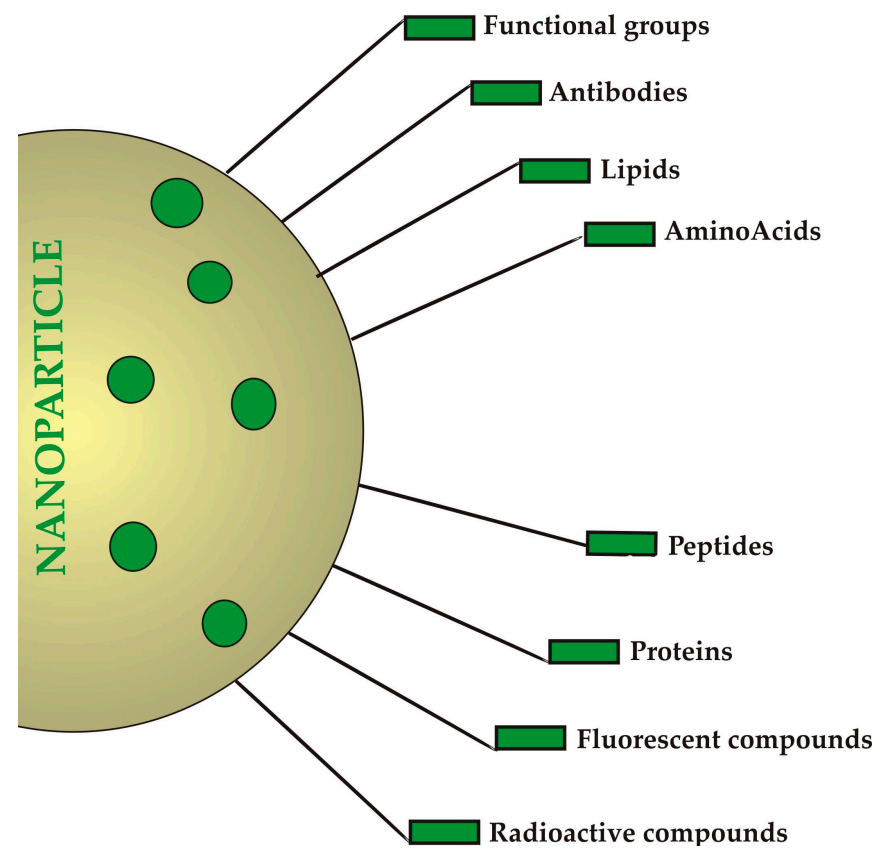

Figure 6. Different approaches to modify surfaces of nanoparticles (NPs) to target cancer cells. 
SynerGene Therapeutics' SGT-94 is a nanocarrier made of cationic liposomes encapsulating RB94 tumor suppressor gene coated with an anti-transferrin receptor (TfR) single-chain antibody fragment. Currently, this nano-sized pharmaceutical dosage form is featured in a Phase I trial in patients diagnosed with genitourinary tumors [49].

Also, the ability to respond to specific environmental stimuli was used to formulate smart dosage forms. The therapeutic agents may be released in a spatiotemporally controlled manner, by using stimuli-responsive NPs with high sensibility to specific microenvironment characteristics [56]. The intrinsic and extrinsic stimuli are mentioned in the Figure 7. These novel mechanisms for controlled drug delivery in cancer therapy are also stated as triggered-release mechanisms.

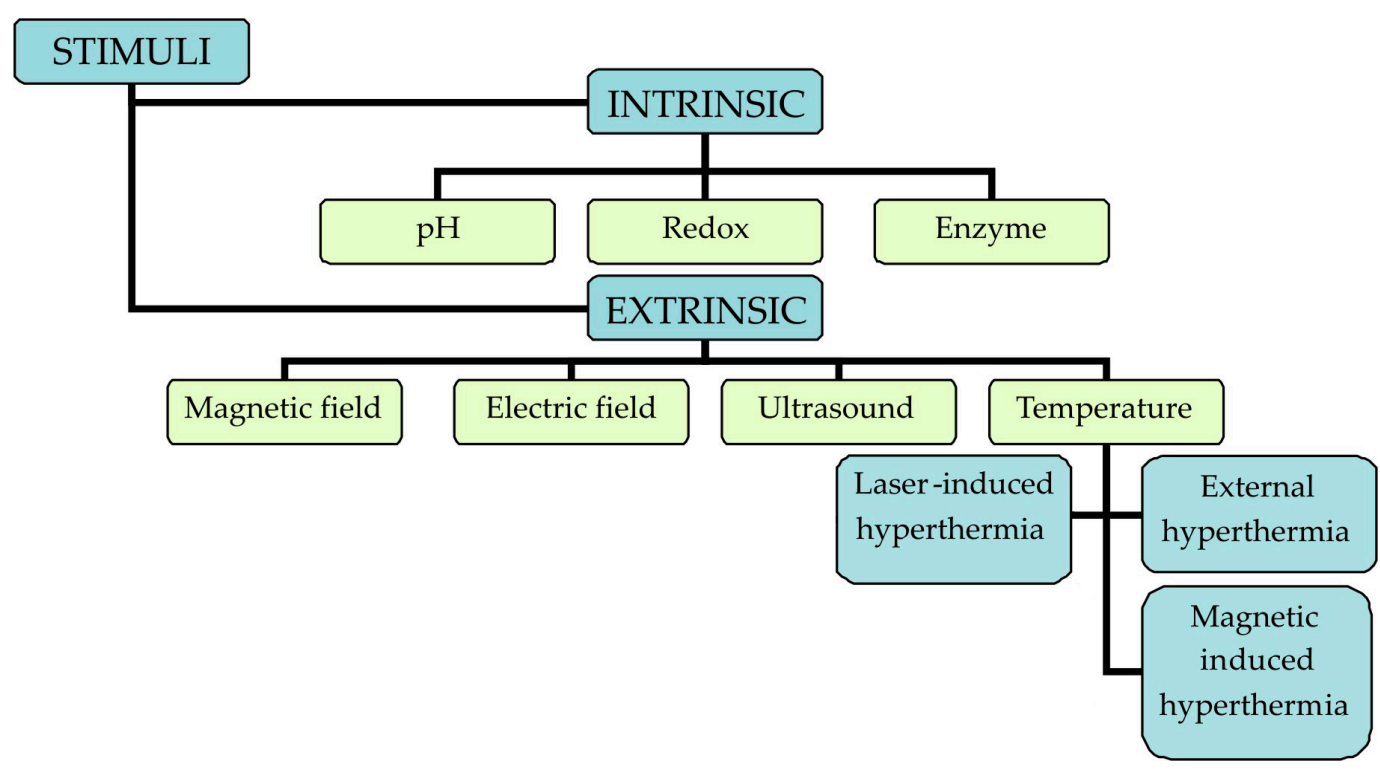

Figure 7. Types of stimuli.

The EPR effect, on which the passive and active targeting is based, has a high biological variability, and therefore sometimes these strategies may fail. To overcome this problem, intravascularly triggered drug release was recently developed. It is based on spatial and temporal drug release control by using internal or external stimuli.

The stimuli involved in the triggered release are either endogenous ( $\mathrm{pH}$, enzymes, redox) or exogenous (temperature, sound, light).

An external magnetic field can be used to transport nanoparticles to tumor sites. Magnetic nanocarriers based on superparamagnetic $\mathrm{Fe}_{2} \mathrm{O}_{3} / \mathrm{NiO}$ functionalized with poly (vinyl alcohol), poly (ethylene oxide) and poly (methacrylic acid) (PMAA) and subsequently conjugated with doxorubicin were studied. A significantly enhanced release rate was observed under magnetic fields [57]. Recently, by using micelles of pentaerythretol poly ( $\varepsilon$-caprolactone) and $\mathrm{Fe}_{3} \mathrm{O}_{4}$, superparamagnetic nanoparticles have been synthesized, achieving a controlled delivery of doxorubicine (DOX) [58]. Also, paclitaxel was delivered using magnetical driven nanoparticles, obtained by incorporating $\mathrm{Fe}_{3} \mathrm{O}_{4}$ in palmitoyl chitosan matrix [59].

The active ingredient can be released in a sustained or pulsed controlled manner, by applying a low intensity external electric field. Unlike other signals, electrical stimuli are easier to generate and control. In this regard, polypyrrole nanoparticles were loaded with therapeutic agents and then incorporated in injectable PLGA-PEG-PLGA hydrogel. The subcutaneous delivery of the drug was controlled by the application of a weak, external electric field [60].

Also, electric controlled NPs of poly(diethyl-4,4'-\{[2,5-bis(2,3-dihydrothieno[3,4-b][1,4]dioxin -5-yl)-1,4-phenylene]bis(oxy)\}dibutanoate) and poly(3,4-ethylenedioxythiophene) (PEDOT) loaded with 4-dodecylbenzenesulfonic acid and poly(4-styrenesulfonic acid-co-maleic acid) were obtained [61]. 
Chitosan-gold nanocomposites were designed as a $\mathrm{pH}$ and electric field responsive systems for a targeted and controlled delivery of 5-FU [62].

The development of new materials in oncology fosters the idea of synergistic heat and chemotherapy use, sustaining the development of photothermal-triggered nanotransporters. A synergistic effect of hyperthermia combined with chemotherapy was demonstrated in several studies by using near-infrared (NIR) irradiation. In one recent study, a magnetite nanocrystal core with polynucleotide shell was loaded 5-FU and anti-HER2 antibody. The tumor remission in vivo was promoted by synergistic effect of drugs combined with hyperthermia-induced ablation [63].

ThermoDox is a thermosensitive liposome loaded with doxorubicin. The mechanism is based on the following process. The phase transition starts when the temperature is rising, and the lipid bilayer of the liposome changes its shape, with doxorubicin being subsequently released. ThermoDox has been tested in a phase III clinical trial involving patients with hepato-cellular carcinomas [64].

Additionally, chitosan-functionalized $\mathrm{MoS}_{2}$ nanosheets were used as (NIR) photothermal-triggered nanotransporters [65].

Synergistic therapy that uses NIR laser irradiation combined with doxorubicin and irinotecan loaded graphene oxide (GO) has been developed to generate heat and to control the delivery of the active principles in breast cancer cells [66].

One study on micelles made of amphiphilic diblock copolymer, poly\{ $\gamma$-2-[2-(2-methoxyethoxy)-

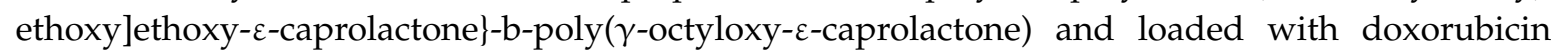
resulted in the efficient thermoresponsive delivery of DOX [67].

Photothermal therapy was also used with biodegradable plasmon resonant liposome gold nanoparticles, showing increased efficiency [68].

The specific features of cancer tissue are very important in determining NPs bioavailability. It is believed that NPs use the mother tumor vessels (first angiogenic blood vessels, derived from normal venules with abnormal plasma proteins hyperpermeability). Inside these tumour vessels, the blood viscosity is increased, determining the NPs to stagnate and, therefore, to accumulate [69]. Also, heterogeneity of the tumor microenvironment remains an important issue in the process of investigating enhanced NPs penetration [29]. For example, it was observed that higher delivery efficiencies tended to be displayed by orthotopic rather than heterotopic tumour models [21].

One of the remaining problems is the animal to human translation. For a $1.0 \%$ ID, the translation of cancer nanoparticles from mouse model to human use is problematic because of the high quantity necessary to be injected (technical aspects of production, physical stability, toxicicity) [21].

By using "nanoparticle" and "cancer" keywords in "Nature" search engines, it can be observed that there are only few studies published in 2019, compared to the large volume of results that these pharmaceutical forms promised. These recent studies are based on finding new strategies that overcome the NPs limitations (inefficient delivery, increased clearance rate, and unspecific targeting).

For example, a novel glioma-targeted nano-system with improved bioavailability was based on energy restriction therapy using menthol-modified albumin as carrier for the co-delivery of albendazole (Abz) and nano-silver on nude mice orthotopic glioma model (inoculated in the caudatoputamen). This study published in 2019 has been proven to suppress tumor growth without adverse effects [70].

Another recent study demonstrated the potential use of nanoparticles of mineral clay to modulate the adhesion between tumor cells and surrounding extracellular matrix [71].

Because of their low tolerability and permeability, currently used chemotherapeutics are not sufficiently effective to treat different types of cancer. Also, multidrug resistance (MDR) is still one of the biggest issues in cancer therapy, mainly due to inefficient drug delivery into the tumor cells, inefficient targeting and rapid removal from tumor cells by P-glycoprotein (P-gp) efflux pump, overexpressed in tumors. Yet, recent studies in the nanotechnology and bioengineering fields offer new approaches that could improve the safety and the efficacy in cancer therapy [72,73]. 


\section{Achieved Objectives-FDA Approved Nanomedicines Used in Cancer Therapy}

Since 1980, when the FDA approved the first medical device based on nanomaterials, commercialization of nanomedicines has been in a continuous growth. In 2017, the FDA released a draft guidance to accelerated approval [74].

Since 1990, more than 40 nanodrugs have been approved for clinical usage by the FDA [75], of which many are implemented in clinical practice [76]. They are mentioned in Tables 1 and 2 respectively. Among these nanoplatforms, liposomal formulations as Doxil (marketed as Caelyx in Canada and Europe), Myocet and DaunoXome are well-known in current practice [77,78].

Table 1. Currently approved nanomedicines in clinical use.

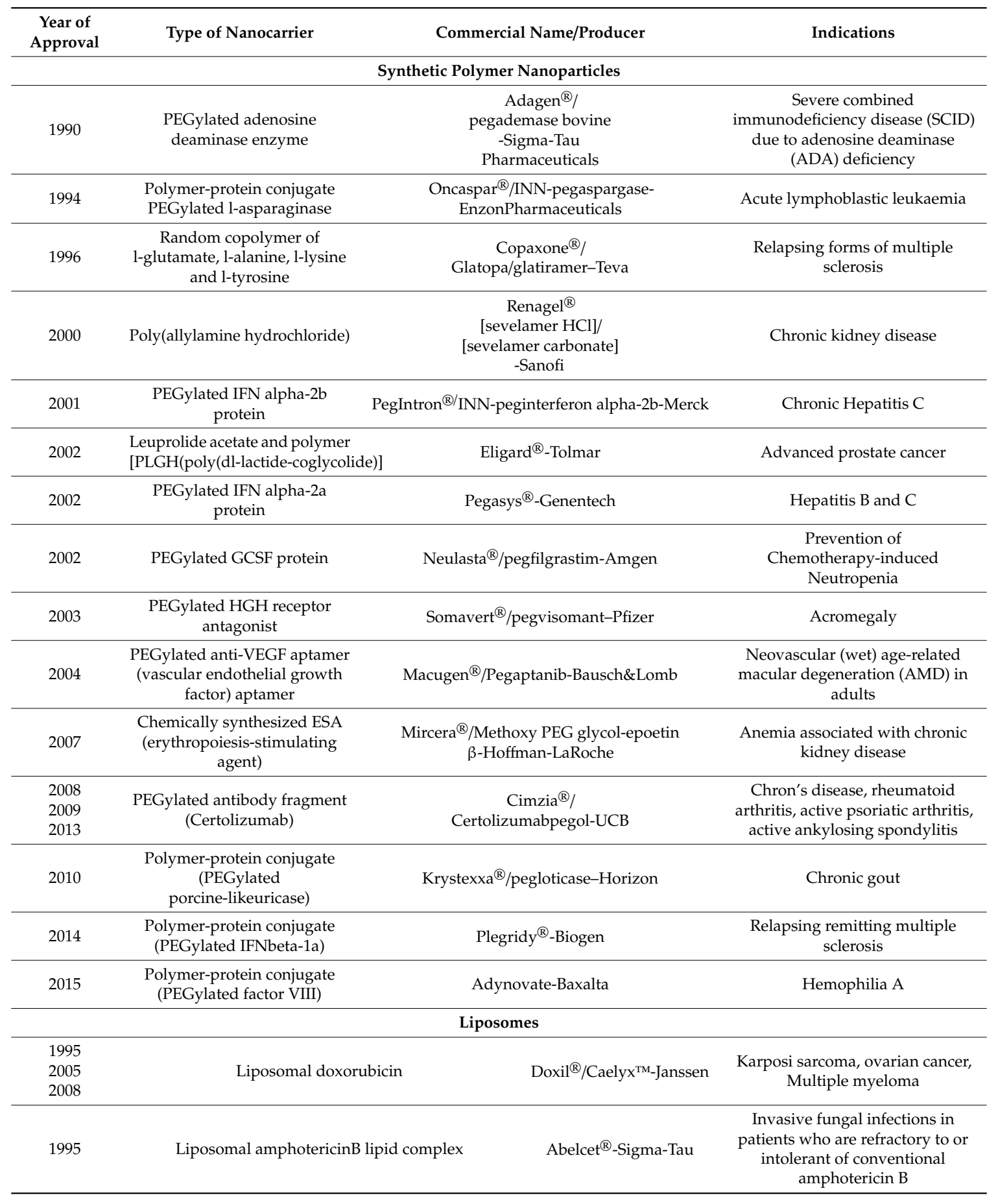


Table 1. Cont.

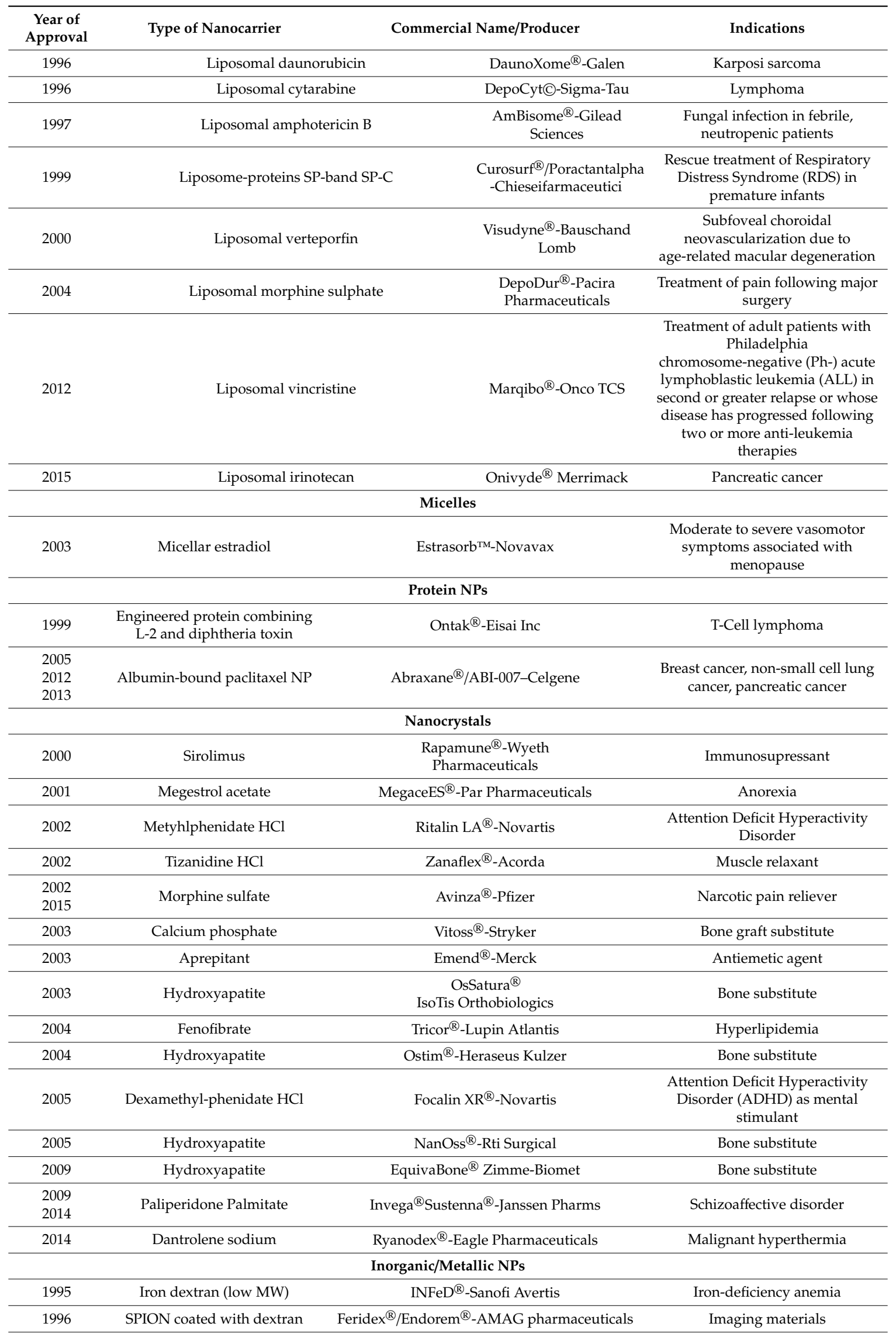


Table 1. Cont.

\begin{tabular}{|c|c|c|c|}
\hline $\begin{array}{c}\text { Year of } \\
\text { Approval }\end{array}$ & Type of Nanocarrier & Commercial Name/Producer & Indications \\
\hline 1997 & Iron dextran (high MW) & DexIron ${ }^{\circledR} /$ Dexferrum ${ }^{\circledR}$-Sanofi Avertis & $\begin{array}{l}\text { Iron deficiency anemia, } \\
\text { hemodialysis-induced }\end{array}$ \\
\hline 1999 & Sodium ferric gluconate & Ferrlecit ${ }^{\circledR}$-Sanofi Avertis & $\begin{array}{c}\text { Iron deficiency anemia in adult } \\
\text { patients and in pediatric patients } \\
\text { age } 6 \text { years and older with chronic } \\
\text { kidney disease receiving } \\
\text { hemodialysis who are receiving } \\
\text { supplemental epoetin therapy }\end{array}$ \\
\hline 2000 & Iron sucrose & $\begin{array}{l}\text { Venofer }^{\circledR} \text {-Luitpold } \\
\text { Pharmaceuticals }\end{array}$ & $\begin{array}{l}\text { Iron deficiency anemia in patients } \\
\text { with chronic kidney disease }\end{array}$ \\
\hline 2008 & SPION coated with dextran & $\begin{array}{l}\text { GastroMARK }^{\mathrm{TM}} / \text { umirem }^{\circledR} \text {-AMAG } \\
\text { pharmaceuticals }\end{array}$ & Imaging materials \\
\hline 2010 & Iron oxide & Nanotherm ${ }^{\circledR}$-MagForce & Hybrid species \\
\hline
\end{tabular}

Table 2. Nanomedicines approved in oncology.

\begin{tabular}{|c|c|c|c|}
\hline Year of Approval & Type of Nanocarrier & $\begin{array}{l}\text { Active Principle- } \\
\text { Commercial Name }\end{array}$ & Indications \\
\hline 1994 (Japan) & $\begin{array}{l}\text { Polymer protein } \\
\text { conjugate }\end{array}$ & $\begin{array}{l}\text { Styrene maleic } \\
\text { anhydride } \\
\text { neocarzinostatin } \\
\text { (SMANCS)- } \\
\text { Zinostatin stimalamer }\end{array}$ & Renal and hepatic cancer \\
\hline 1996 & Iron oxide NPs & Ferumoxides-Feridex & $\begin{array}{l}\text { i.v. administration as an adjunct to MRI (in } \\
\text { adult patients) to enhance the T } 2 \text { weighted } \\
\text { images used in the detection and } \\
\text { evaluation of lesions of the liver that are } \\
\text { associated with an alteration in the RES }\end{array}$ \\
\hline $\begin{array}{l}1995 \text { (FDA) } \\
1996 \text { (EMA) }\end{array}$ & Liposome (PEGylated) & Doxorubicin-Doxil/Caelyx & $\begin{array}{l}\text { HIV-associated Kaposi's } \\
\text { sarcoma, ovarian cancer, } \\
\text { metastatic breast cancer, } \\
\text { multiple myeloma }\end{array}$ \\
\hline 1996 (FDA) & $\begin{array}{l}\text { Liposome (non- } \\
\text { PEGylated) }\end{array}$ & Daunorubicin-DaunoXome & $\begin{array}{l}\text { HIV-associated Kaposi's } \\
\text { Sarcoma }\end{array}$ \\
\hline 1998 (Taiwan) & Liposome & Doxorubicin-Lipo-Dox & $\begin{array}{l}\text { Kaposi's sarcoma, breast } \\
\text { and ovarian cancer }\end{array}$ \\
\hline 1999 (FDA) & Liposome & $\begin{array}{l}\text { Cytosine arabinoside } \\
\text { (cytarabine)-DepoCyt }\end{array}$ & Neoplastic meningitis \\
\hline 2000 (EMA) & Liposome & Doxorubicin-Myocet & Breast cancer \\
\hline $\begin{array}{l}2005 \text { (FDA) } \\
2008 \text { (EMA) }\end{array}$ & $\begin{array}{l}\text { Nanoparticle albumin } \\
\text { Bound }\end{array}$ & Paclitaxel-Abraxane & $\begin{array}{l}\text { Advanced non-small-cell } \\
\text { lung cancer, metastatic } \\
\text { pancreatic cancer, metastatic } \\
\text { breast cancer }\end{array}$ \\
\hline 2006 (FDA) & PEG protein conjugate & 1-Asparaginase-Oncaspar & Leukemia \\
\hline 2007 (South Korea) & $\begin{array}{l}\text { PEG-PLA polymeric } \\
\text { Micelle }\end{array}$ & Paclitaxel-Genexol-PM & $\begin{array}{l}\text { Breast cancer, Lung cancer, } \\
\text { Ovarian cancer }\end{array}$ \\
\hline 2002 & Polymeric NP & $\begin{array}{c}\text { Leuprolide } \\
\text { acetate-Eligard }\end{array}$ & Prostate cancer \\
\hline 2009 (EMA) & $\begin{array}{l}\text { Liposome (non- } \\
\text { PEGylated) }\end{array}$ & Mifamurtide-MEPACT & Osteosarcoma \\
\hline 2010 (EMA) & Iron oxide nanoparticle & NanoTherm & Glioblastoma \\
\hline 2012 (FDA) & $\begin{array}{l}\text { Liposome (non- } \\
\text { PEGylated) }\end{array}$ & Vincristine-Marqibo & $\begin{array}{c}\text { Philadelphia chromosome } \\
\text { negative acute lymphoblastic } \\
\text { leukemia }\end{array}$ \\
\hline 2015 (FDA) & Liposome (PEGylated) & Irinotecan/MM-398-Onivyde & $\begin{array}{l}\text { Metastatic pancreatic } \\
\text { cancer }\end{array}$ \\
\hline
\end{tabular}




\section{Limitations}

One of the problems that must be overcome in the field of oncology is the development of effective treatments that have specificity and selectivity for tumor cells. In this regard, some solutions come from nanotechnology which seems to promise new cancer treatment options. Therefore, nano-sized pharmaceutical dosage forms with ability to deliver the active principle in a controlled manner and to the specific target were obtained. These delivery systems were investigated on animal models and those that presented satisfactory results, advanced further into the clinical study phases. In the end, only a few succeeded in being approved for usage in current guidelines [79].

Research shows that molecular targeting fields come with many advantages that prove to be very well combined with those of nanomedicine: active targeting moiety, real-time in vivo imaging, controlled drug release, active targeting and real-time monitoring [80,81]. However, there are many issues that have not yet been resolved. The current principles used for NP targeting have not led the desired clinical results. The causes of poor delivery efficiency may originate both into tumour biology (transport mechanisms, EPR effect) and into competing organs (renal and mononuclear phagocytic systems). For example, an analysis performed by Wilhelm et al. 2016, revealed that only $0.7 \%$ of the injected dose (ID) of nanoparticles reached the solid tumour in a mouse model and that efficiency did not improve, even 10 years later [21].

To a certain extent, technical aspects restrict the clinical implementation of nanomedicine, such as: the small number of relevant in vivo/ex vivo models, specific to the nanodrugs administration pathways; the small number of in silico models to be used to extrapolate toxicology data; not enough information about in vivo interactions between nanomaterials and biomolecules; not enough pharmacokinetic data of and in vitro/in vivo correlation concerning nanodrugs; low number and low standardization of validated in vitro test protocols $[82,83]$.

\section{Conclusions}

Data from the literature suggest that nanoparticles have potential in diagnosis and therapy for several cancer types, due to their small size and their highly modifiable physical, chemical, and biological properties. In addition, by enhanced targetability, nanoparticles also enhance cytostatics penetration of biological barriers, making the therapy more specific and efficient. Unfortunately, the progresses in this area have been below the initial expectations. Despite the major investments made in this area and the promising results in treating tumours using mouse models, these advantages of nanoparticles have been overshadowed by the lack of translation to human patients. Although some of these materials have not been successful upon their clinical translation, several new and promising materials that are currently under development show great promise, thereby providing hope for new treatment options in the near future.

The potential therapeutic value of nanomedicine is huge as several functions for drug delivery and imaging can be simultaneously incorporated. Examples include multistep cancer targeting strategies and multimodal imaging agents, as described above. With the additional consideration of using nanoparticles to engineer targeting cells like MSCs, or using targeting MSCs to deliver nanoparticles, even more potential treatment paradigms are possible. Nanotechnology can allow researchers to develop novel strategies for delivering drug cargos and imaging agents, while also making good use of their chemical flexibility to modify and functionalize nanoparticles, which may lead to a more comprehensive therapy for cancer.

Author Contributions: Conceptualization, A.-S.S., C.H., S.T. and A.D.; Formal Analysis S.C.B., C.E.C. and M.M.D., Writing-Original Draft Preparation, A.-S.S., C.H., and S.A.A.; Data Curation, B.I.V. and C.T.; Writing-Review \& Editing, S.T. and A.D.; Funding Acquisition, A.D.

Funding: This work was supported by the UEFISCDI, Romania through the PN-II-ID-PCE-2011-3-1041 Grant.

Conflicts of Interest: The authors declare no conflict of interest. 


\section{References}

1. Siegel, R.L.; Miller, K.D.; Jemal, A. Cancer statistics, 2019. CA Cancer J. Clin. 2019, 69, 7-34. [CrossRef] [PubMed]

2. Mukherjee, S. Genomics-guided immunotherapy for precision medicine in cancer. Cancer Biother. Radiopharm. 2019. [CrossRef] [PubMed]

3. Wang, M.; Xie, Y.T.; Girnita, L.; Nilsson, G.; Dricu, A.; Wejde, J.; Larsson, O. Regulatory role of mevalonate and N-linked glycosylation in proliferation and expression of the EWS/FLI-1 fusion protein in Ewing's sarcoma cells. Exp. Cell Res. 1999, 246, 38-46. [CrossRef] [PubMed]

4. Cosaceanu, D.; Carapancea, M.; Budiu, R.; Martinsson, H.-S.; Starborg, M.; Vrabete, M.; Kanter, L.; Lewensohn, R.; Dricu, A. Comparison of three approaches for inhibiting insulin-like growth factor I receptor and their effects on NSCLC cell lines in vitro. Growth Factors 2007, 25, 1-8. [CrossRef] [PubMed]

5. Umemoto, S.; Haruta, M.; Sakisaka, M.; Ikeda, T.; Tsukamoto, H.; Komohara, Y.; Takeya, M.; Nishimura, Y.; Senju, S. Cancer therapy with MHC-deficient and interferon $\beta$-producing myeloid cells derived from allogeneic embryonic stem cells. Cancer Sci. 2019. [CrossRef] [PubMed]

6. Carapancea, M.; Alexandru, O.; Fetea, A.S.; Dragutescu, L.; Castro, J.; Georgescu, A.; Popa-Wagner, A.; Backlund, M.L.; Lewensohn, R.; Dricu, A. Growth factor receptors signaling in glioblastoma cells: Therapeutic implications. J. Neurooncol. 2009, 92, 137-147. [CrossRef] [PubMed]

7. Dhar, S.; Gu, F.X.; Langer, R.; Farokhzad, O.C.; Lippard, S.J. Targeted delivery of cisplatin to prostate cancer cells by aptamer functionalized Pt(IV) prodrug-PLGA-PEG nanoparticles. Proc. Natl. Acad. Sci. USA 2008, 105, 17356-17361. [CrossRef] [PubMed]

8. Albanese, A.; Tang, P.S.; Chan, W.C. The effect of nanoparticle size, shape, and surface chemistry on biological systems. Annu. Rev. Biomed. Eng. 2012, 14,1-16. [CrossRef] [PubMed]

9. Wicki, A.; Witzigmann, D.; Balasubramanian, V.; Huwyler, J. Nanomedicine in cancer therapy: Challenges, opportunities, and clinical applications. J. Control. Release 2015, 200, 138-157. [CrossRef]

10. Jeevanandam, J.; Barhoum, A.; Chan, Y.S.; Dufresne, A.; Danquah, M.K. Review on nanoparticles and nanostructured materials: History, sources, toxicity and regulations. Beilstein J. Nanotechnol. 2018, 9, 1050-1074. [CrossRef]

11. Palazzolo, S.; Bayda, S.; Hadla, M.; Caligiuri, I.; Corona, G.; Toffoli, G.; Rizzolio, F. The clinical translation of organic nanomaterials for cancer therapy: A focus on polymeric nanoparticles, micelles, liposomes and exosomes. Curr. Med. Chem. 2018, 25, 4224-4268. [CrossRef] [PubMed]

12. Bayda, S.; Hadla, M.; Palazzolo, S.; Riello, P.; Corona, G.; Toffoli, G.; Rizzolio, F. Inorganic nanoparticles for cancer therapy: A transition from lab to clinic. Curr. Med. Chem. 2018, 25, 4269-4303. [CrossRef] [PubMed]

13. Pokropivny, V.V.; Skorokhod, V.V. Classification of nanostructures by dimensionality and concept of surface forms engineering in nanomaterial science. Mater. Sci. Eng. C 2007, 27, 990-993. [CrossRef]

14. Wagner, S.; Gondikas, A.; Neubauer, E.; Hofmann, T.; von der Kammer, F. Spot the difference: Engineered and natural nanoparticles in the environment-Release, behavior, and fate. Angew. Chem. Int. Ed. 2014, 53, 12398-12419. [CrossRef] [PubMed]

15. Sanchis, A.; Salvador, J.P.; Marco, M.P. Light-induced mechanisms for nanocarrier's cargo release. Colloids Surf. B Biointerfaces 2019, 173, 825-832. [CrossRef]

16. Florence, A.T. "Targeting" nanoparticles: The constraints of physical laws and physical barriers. J. Control. Release 2012, 164, 115-124. [CrossRef]

17. Nichols, J.W.; Bae, Y.H. Odyssey of a cancer nanoparticle: From injection site to site of action. Nano Today 2012, 7, 606-618. [CrossRef]

18. Lazarovits, J.; Chen, Y.Y.; Sykes, E.A.; Chan, W.C.W. Nanoparticle-blood interactions: The implications on solid tumour targeting. Chem. Commun. 2015, 51, 2756-2767. [CrossRef]

19. Blanco, E.; Shen, H.; Ferrari, M. Principles of nanoparticle design for overcoming biological barriers to drug delivery. Nat. Biotechnol. 2015, 33, 941-951. [CrossRef]

20. Saraiva, C.; Praca, C.; Ferreira, R.; Santos, T.; Ferreira, L.; Bernardino, L. Nanoparticle-mediated brain drug delivery: Overcoming blood-brain barrier to treat neurodegenerative diseases. J. Control. Release 2016, 235, 34-47. [CrossRef]

21. Wilhelm, S.; Tavares, A.J.; Dai, Q.; Ohta, S.; Audet, J.; Dvorak, H.F.; Chan, W.C.W. Analysis of nanoparticle delivery to tumours. Nat. Rev. Mater. 2016, 1, 16014. [CrossRef] 
22. Zhao, Y.; Wang, Y.; Ran, F.; Cui, Y.; Liu, C.; Zhao, Q.; Gao, Y.; Wang, D.; Wang, S. A comparison between sphere and rod nanoparticles regarding their in vivo biological behavior and pharmacokinetics. Sci. Rep. 2017, 7, 4131. [CrossRef]

23. Stylianopoulos, T.; Poh, M.-Z.; Insin, N.; Bawendi, M.G.; Fukumura, D.; Munn, L.L.; Jain, R.K. Diffusion of particles in the extracellular matrix: The effect of repulsive electrostatic interactions. Biophys. J. 2010, 99, 1342-1349. [CrossRef] [PubMed]

24. Nel, A.E.; Mädler, L.; Velegol, D.; Xia, T.; Hoek, E.M.; Somasundaran, P.; Klaessig, F.; Castranova, V.; Thompson, M. Understanding biophysicochemical interactions at the nano-bio interface. Nat. Mater. 2009, 8, 543-557. [CrossRef] [PubMed]

25. Din, F.U.; Aman, W.; Ullah, I.; Qureshi, O.S.; Mustapha, O.; Shafique, S.; Zeb, A. Effective use of nanocarriers as drug delivery systems for the treatment of selected tumors. Int. J. Nanomed. 2017, 12, 7291-7309. [CrossRef] [PubMed]

26. Zhang, R.X.; Ahmed, T.; Li, L.Y.; Li, J.; Abbasi, A.Z.; Wu, X.Y. Design of nanocarriers for nanoscale drug delivery to enhance cancer treatment using hybrid polymer and lipid building blocks. Nanoscale 2017, 9, 1334-1355. [CrossRef] [PubMed]

27. Rodriguez, P.L.; Harada, T.; Christian, D.A.; Pantano, D.A.; Tsai, R.K.; Discher, D.E. Minimal "Self" peptides that inhibit phagocytic clearance and enhance delivery of nanoparticles. Science 2013, 339, 971-975. [CrossRef] [PubMed]

28. Nie, S. Understanding and overcoming major barriers in cancer nanomedicine. Nanomedicine 2010, 5, 523-528. [CrossRef] [PubMed]

29. von Roemeling, C.; Jiang, W.; Chan, C.K.; Weissman, I.L.; Kim, B.Y. Breaking down the barriers to precision cancer nanomedicine. Trends Biotechnol. 2017, 35, 159-171. [CrossRef]

30. Jackson, M.A.; Werfel, T.A.; Curvino, E.J.; Yu, F.; Kavanaugh, T.E.; Sarett, S.M.; Dockery, M.D.; Kilchrist, K.V.; Jackson, A.N.; Giorgio, T.D.; et al. Zwitterionic nanocarrier surface chemistry improves siRNA tumor delivery and silencing activity relative to polyethylene glycol. ACS Nano 2017, 11, 5680-5696. [CrossRef]

31. Fang, R.H.; Kroll, A.V.; Gao, W.; Zhang, L. Cell membrane coating nanotechnology. Adv. Mater. 2018, 30, e1706759. [CrossRef]

32. Duan, X.; Li, Y. Physicochemical characteristics of nanoparticles affect circulation, biodistribution, cellular internalization, and trafficking. Small 2013, 9, 1521-1532. [CrossRef] [PubMed]

33. Hoshyar, N.; Gray, S.; Han, H.; Bao, G. The effect of nanoparticle size on in vivo pharmacokinetics and cellular interaction. Nanomedicine 2016, 11, 673-692. [CrossRef] [PubMed]

34. Ruggiero, A.; Villa, C.H.; Bander, E.; Rey, D.A.; Bergkvist, M.; Batt, C.A.; Manova-Todorova, K.; Deen, W.M.; Scheinberg, D.A.; McDevitt, M.R. Paradoxical glomerular filtration of carbon nanotubes. Proc. Natl. Acad. Sci. USA 2010, 107, 12369-12374. [CrossRef] [PubMed]

35. Pardridge, W.M. The blood-brain barrier: Bottleneck in brain drug development. NeuroRx J. Am. Soc. Exp. Neurother. 2005, 2, 3-14. [CrossRef] [PubMed]

36. Grabrucker, A.M.; Ruozi, B.; Belletti, D.; Pederzoli, F.; Forni, F.; Vandelli, M.A.; Tosi, G. Nanoparticle transport across the blood brain barrier. Tissue Barriers 2016, 4, e1153568. [CrossRef] [PubMed]

37. Lajoie, J.M.; Shusta, E.V. Targeting receptor-mediated transport for delivery of biologics across the blood-brain barrier. Annu. Rev. Pharmacol. Toxicol. 2015, 55, 613-631. [CrossRef] [PubMed]

38. Kreuter, J. Mechanism of polymeric nanoparticle-based drug transport across the blood-brain barrier (BBB). J. Microencapsul. 2013, 30, 49-54. [CrossRef] [PubMed]

39. Zensi, A.; Begley, D.; Pontikis, C.; Legros, C.; Mihoreanu, L.; Buchel, C.; Kreuter, J. Human serum albumin nanoparticles modified with apolipoprotein A-I cross the blood-brain barrier and enter the rodent brain. J. Drug Target. 2010, 18, 842-848. [CrossRef] [PubMed]

40. Hu, K.; Li, J.; Shen, Y.; Lu, W.; Gao, X.; Zhang, Q.; Jiang, X. Lactoferrin-conjugated PEG-PLA nanoparticles with improved brain delivery: In vitro and in vivo evaluations. J. Control. Release 2009, 134, 55-61. [CrossRef] [PubMed]

41. Ulbrich, K.; Hekmatara, T.; Herbert, E.; Kreuter, J. Transferrin-and transferrin-receptor-antibody-modified nanoparticles enable drug delivery across the blood-brain barrier (BBB). Eur. J. Pharm. Biopharm. 2009, 71, 251-256. [CrossRef] [PubMed] 
42. Kim, H.R.; Gil, S.; Andrieux, K.; Nicolas, V.; Appel, M.; Chacun, H.; Desmaële, D.; Taran, F.; Georgin, D.; Couvreur, P. Low-density lipoprotein receptor-mediated endocytosis of PEGylated nanoparticles in rat brain endothelial cells. Cell. Mol. Life Sci. 2007, 64, 356-364. [CrossRef] [PubMed]

43. Shilo, M.; Sharon, A.; Baranes, K.; Motiei, M.; Lellouche, J.-P.M.; Popovtzer, R. The effect of nanoparticle size on the probability to cross the blood-brain barrier: An in vitro endothelial cell model. J. Nanobiotechnol. 2015, 13, 19. [CrossRef] [PubMed]

44. Lockman, P.R.; Koziara, J.M.; Mumper, R.J.; Allen, D.D. Nanoparticle surface charges alter blood-brain barrier integrity and permeability. J. Drug Target. 2004, 12, 635-641. [CrossRef] [PubMed]

45. Feng, D.; Nagy, J.A.; Hipp, J.; Dvorak, H.F.; Dvorak, A.M. Vesiculo-vacuolar organelles and the regulation of venule permeability to macromolecules by vascular permeability factor, histamine, and serotonin. J. Exp. Med. 1996, 183, 1981-1986. [CrossRef]

46. Golombek, S.K.; May, J.N.; Theek, B.; Appold, L.; Drude, N.; Kiessling, F.; Lammers, T. Tumor targeting via EPR: Strategies to enhance patient responses. Adv. Drug Deliv. Rev. 2018, 130, 17-38. [CrossRef]

47. Basha, M. Nanotechnology as a promising strategy for anticancer drug delivery. Curr. Drug Deliv. 2018, 15, 497-509. [CrossRef]

48. Suk, J.S.; Xu, Q.; Kim, N.; Hanes, J.; Ensign, L.M. PEGylation as a strategy for improving nanoparticle-based drug and gene delivery. Adv. Drug Deliv. Rev. 2016, 99, 28-51. [CrossRef]

49. Rosenblum, D.; Joshi, N.; Tao, W.; Karp, J.M.; Peer, D. Progress and challenges towards targeted delivery of cancer therapeutics. Nat. Commun. 2018, 9, 1410. [CrossRef]

50. Bertrand, N.; Wu, J.; Xu, X.; Kamaly, N.; Farokhzad, O.C. Cancer nanotechnology: The impact of passive and active targeting in the era of modern cancer biology. Adv. Drug Deliv. Rev. 2014, 66, 2-25. [CrossRef]

51. Sun, T.; Wu, H.; Li, Y.; Huang, Y.; Yao, L.; Chen, X.; Du, Z. Targeting transferrin receptor delivery of temozolomide for a potential glioma stem cell-mediated therapy. Oncotarget 2017, 8, 74451-74465. [CrossRef] [PubMed]

52. Gupta, B.; Torchilin, V.P. Monoclonal antibody 2C5-modified doxorubicin-loaded liposomes with significantly enhanced therapeutic activity against intracranial human brain U-87 MG tumor xenografts in nude mice. Cancer Immunol. Immunother. 2007, 56, 1215-1223. [CrossRef] [PubMed]

53. Quadir, M.A.; Morton, S.W.; Mensah, L.B.; Shopsowitz, K.; Dobbelaar, J.; Effenberger, N.; Hammond, P.T. Ligand-decorated click polypeptide derived nanoparticles for targeted drug delivery applications. Nanomed. Nanotechnol. Biol. Med. 2017, 13, 1797-1808. [CrossRef] [PubMed]

54. Morozova, O.V.; Pavlova, E.R.; Bagrov, D.V.; Barinov, N.A.; Prusakov, K.A.; Isaeva, E.I.; Podgorsky, V.V.; Basmanov, D.V.; Klinov, D.V. Protein nanoparticles with ligand-binding and enzymatic activities. Int. J. Nanomed. 2018, 13, 6637-6646. [CrossRef] [PubMed]

55. Sayers, E.J.; Magnusson, J.P.; Moody, P.R.; Mastrotto, F.; Conte, C.; Brazzale, C.; Borri, P.; Caliceti, P.; Watson, P.; Mantovani, G.; et al. Switching of macromolecular ligand display by thermoresponsive polymers mediates endocytosis of multiconjugate nanoparticles. Bioconjug. Chem. 2018, 29, 1030-1046. [CrossRef] [PubMed]

56. Alavizadeh, S.H.; Soltani, F.; Ramezani, M. Recent advances in immunoliposome-based cancer therapy. Curr. Pharmacol. Rep. 2016, 2, 129-141. [CrossRef]

57. Rana, S.; Gallo, A.; Srivastava, R.S.; Misra, R.D.K. On the suitability of nanocrystalline ferrites as a magnetic carrier for drug delivery: Functionalization, conjugation and drug release kinetics. Acta Biomater. 2007, 3, 233-242. [CrossRef]

58. Panja, S.; Maji, S.; Maiti, T.K.; Chattopadhyay, S. A smart magnetically active nanovehicle for on-demand targeted drug delivery: Where van der waals force balances the magnetic interaction. ACS Appl. Mater. Interfaces 2015, 7, 24229-24241. [CrossRef]

59. Mansouri, M.; Nazarpak, M.H.; Solouk, A.; Akbari, S.; Hasani-Sadrabadi, M.M. Magnetic responsive of paclitaxel delivery system based on SPION and palmitoyl chitosan. J. Magn. Magn. Mater. 2017, 421, 316-325. [CrossRef]

60. Ge, J.; Neofytou, E.; Cahill, T.J.; Beygui, R.E.; Zare, R.N. Drug release from electric-field-responsive nanoparticles. ACS Nano 2012, 6, 227-233. [CrossRef]

61. Cantu, T.; Walsh, K.; Pattani, V.P.; Moy, A.J.; Tunnell, J.W.; Irvin, J.A.; Betancourt, T. Conductive polymer-based nanoparticles for laser-mediated photothermal ablation of cancer: Synthesis, characterization, and in vitro evaluation. Int. J. Nanomed. 2017, 12, 615-632. [CrossRef] [PubMed] 
62. Chandran, P.R.; Sandhyarani, N. An electric field responsive drug delivery system based on chitosan-gold nanocomposites for site specific and controlled delivery of 5-fluorouracil. RSC Adv. 2014, 4, 44922-44929. [CrossRef]

63. Li, T.J.; Huang, C.C.; Ruan, P.W.; Chuang, K.Y.; Huang, K.J.; Shieh, D.B.; Yeh, C.S. In vivo anti-cancer efficacy of magnetite nanocrystal-based system using locoregional hyperthermia combined with 5-fluorouracil chemotherapy. Biomaterials 2013, 34, 7873-7883. [CrossRef] [PubMed]

64. Thermodox. Available online: http://investor.celsion.com/news-releases/news-release-details/celsionprovides-update-thermodoxr-phase-iii-optima-study (accessed on 15 June 2019).

65. Yin, W.; Yan, L.; Yu, J.; Tian, G.; Zhou, L.; Zheng, X.; Zhang, X.; Yong, Y.; Li, J.; Gu, Z.; et al. High-throughput synthesis of single-layer $\mathrm{MoS}_{2}$ nanosheets as a near-infrared photothermal-triggered drug delivery for effective cancer therapy. ACS Nano 2014, 8, 6922-6933. [CrossRef] [PubMed]

66. Tran, T.H.; Nguyen, H.T.; Pham, T.T.; Choi, J.Y.; Choi, H.G.; Yong, C.S.; Kim, J.O. Development of a graphene oxide nanocarrier for dual-drug chemo-phototherapy to overcome drug resistance in cancer. ACS Appl. Mater. Interfaces 2015, 7, 28647-28655. [CrossRef] [PubMed]

67. Cheng, Y.; Hao, J.; Lee, L.A.; Biewer, M.C.; Wang, Q.; Stefan, M.C. Thermally controlled release of anticancer drug from selfassembled $\gamma$-substituted amphiphilic poly( $\varepsilon$-caprolactone) micellar nanoparticles. Biomacromolecules 2012, 13, 2163-2173. [CrossRef] [PubMed]

68. Vines, J.B.; Yoon, J.H.; Ryu, N.E.; Lim, D.J.; Park, H. Gold nanoparticles for photothermal cancer therapy. Front. Chem. 2019, 7, 167. [CrossRef] [PubMed]

69. Chang, S.H.; Kanasaki, K.; Gocheva, V.; Blum, G.; Harper, J.; Moses, M.A.; Shih, S.C.; Nagy, J.A.; Joyce, J.; Bogyo, M.; et al. VEGF-A induces angiogenesis by perturbing the cathepsin-cysteine protease inhibitor balance in venules, causing basement membrane degradation and mother vessel formation. Cancer Res. 2009, 69, 4537-4544. [CrossRef] [PubMed]

70. Liang, J.; Zhu, Y.; Gao, C.; Ling, C.; Qin, J.; Wang, Q.; Huang, Y.; Lu, W.; Wang, J. Menthol-modified BSA nanoparticles for glioma targeting therapy using an energy restriction strategy. NPG Asia Mater. 2019, 11, 38. [CrossRef]

71. Sahel, N.A.; Habib-ur-Rehman, A. Enhancing cancer cell adhesion with clay nanoparticles for countering metastasis. Sci. Rep. 2019, 9, 5935. [CrossRef]

72. Riley, R.S.; June, C.H.; Langer, R.; Mitchell, M.J. Delivery technologies for cancer immunotherapy. Nat. Rev. Drug Discov. 2019, 18, 175-196. [CrossRef] [PubMed]

73. Singh, A.P.; Biswas, A.; Shukla, A.; Maiti, P. Targeted therapy in chronic diseases using nanomaterial-based drug delivery vehicles. Signal Transduct. Target. Ther. 2019, 4, 33. [CrossRef]

74. FDA Guidance. Drug Products, Including Biological Products, that Contain Nanomaterials-Guidance for Industry. Available online: https:/www.fda.gov/regulatory-information/search-fda-guidance-documents/ drug-products-including-biological-products-contain-nanomaterials-guidance-industry (accessed on 30 July 2019).

75. Choi, Y.H.; Han, H.-K. Nanomedicines: Current status and future perspectives in aspect of drug delivery and pharmacokinetics. J. Pharm. Investig. 2018, 48, 43-60. [CrossRef]

76. Bor, G.; Mat Azmi, I.D.; Yaghmur, A. Nanomedicines for cancer therapy: Current status, challenges and future prospects. Ther. Deliv. 2019, 10, 113-132. [CrossRef] [PubMed]

77. Bobo, D.; Robinson, K.J.; Islam, J.; Thurecht, K.J.; Corrie, S.R. Nanoparticle-based medicines: A review of FDA-approved materials and clinical trials to date. Pharm. Res. 2016, 33, 2373-2387. [CrossRef] [PubMed]

78. Food and Drug Administration. Novel Drug Approvals for 2017. Available online: www.fda.gov/drugs/ developmentapprovalprocess/druginnovation/ucm537040 (accessed on 20 July 2019).

79. Kam, N.W.S.; Liu, Z.; Dai, H. Functionalization of carbon nanotubes via cleavable disulfide bonds for efficient intracellular delivery of siRNA and potent gene silencing. J. Am. Chem. Soc. 2005, 127, 12492-12493. [CrossRef]

80. McCarthy, J.R.; Weissleder, R. Multifunctional magnetic nanoparticles for targeted imaging and therapy. Adv. Drug Deliv. Rev. 2008, 60, 1241-1251. [CrossRef]

81. Symens, N.; Walczak, R.; Demeester, J.; Mattaj, I.; de Smedt, S.C.; Remaut, K. Nuclear inclusion of nontargeted and chromatin-targeted polystyrene beads and plasmid DNA containing nanoparticles. Mol. Pharm. 2011, 8, 1757-1766. [CrossRef] 
82. Hafner, A.; Lovrić, J.; Lakoš, G.P.; Pepić, I. Nanotherapeutics in the EU: An overview on current state and future directions. Int. J. Nanomed. 2014, 9, 1005-1023. [CrossRef]

83. Nyström, A.M.; Fadeel, B. Safety assessment of nanomaterials: Implications for nanomedicine. J. Control. Release 2012, 161, 403-408. [CrossRef]

(C) 2019 by the authors. Licensee MDPI, Basel, Switzerland. This article is an open access article distributed under the terms and conditions of the Creative Commons Attribution (CC BY) license (http://creativecommons.org/licenses/by/4.0/). 